\author{
Візуальні та довізуальні МРТ-критерії \\ у пацієнтів середнього віку: \\ клініко-нейровізуалізаційні кореляції \\ Семьонова O.B. ${ }^{1,2}$, ORCID: 0000-0001-5642-1312, e-mail: al.semenova@i.ua \\ Мироняк Л.A. ${ }^{1}$, ORCID: 0000-0002-7115-9516, e-mail: L.myronyak2017@gmail.com \\ Глазовська I.I. ${ }^{1}$, ORCID: 0000-0001-8203-8421, e-mail: iglazovska@gmail.com \\ Іванова М.Ф. ${ }^{1}$, ORCID: 0000-0001-6212-9633, e-mail: mf_ivanova@i.ua \\ Красюк O.A. ${ }^{3}$, ORCID: 0000-0003-2869-9282, e-mail: alexkrasyuk@ukr.net \\ ${ }^{1}$ Державна установа «Iнститут ядерної медицини та променевої діагностики \\ Національної академії медичних наук України», Київ, Україна \\ ${ }^{2}$ Національний університет охорони здоров'я України ім. П.Л. Шупика \\ Міністерства охорони здоров'я України, Київ, Україна \\ 'Українська військово-медична академія \\ Міністерства оборони України, Київ, Україна
} ранньої діагностики церебральної хвороби малих судин

\title{
Visual and previsual MRI-criteria for early diagnosis of cerebral small vessels disease in middle-aged patients: clinical and neuroimaging correlations
}

Semonova O.V.1,2, ORCID: 0000-0001-5642-1312, e-mail: al.semenova@i.ua Myronyak L.A. ${ }^{1}$, ORCID: 0000-0002-7115-9516, e-mail: L.myronyak2017@gmail.com Glazovska I.I. ${ }^{1}$, ORCID: 0000-0001-8203-8421, e-mail: iglazovska@gmail.com Ivanova M.F. ${ }^{1}$, ORCID: 0000-0001-6212-9633, e-mail: mf_ivanova@i.ua Krasyuk O.A. ${ }^{3}$, ORCID: 0000-0003-2869-9282, e-mail: alexkrasyuk@ukr.net

${ }^{1}$ State institution «Institute Nuclear Medicine and Diagnostic Radiology of National Academy of Medical Science of Ukraine», Kyiv, Ukraine ${ }^{2}$ Shupyk National Healthcare University of Ukraine of the Ministry of Health of Ukraine, Kyiv, Ukraine ${ }^{3}$ Military medical academy of Ukraine of the Ministry of Defense of Ukraine, Kyiv, Ukraine

\section{Ключові слова:}

церебральна хвороба малих судин, рання МРТ-діагностика, ранні помірні когнітивні порушення.

\section{Для кореспонденції:}

Семьонова Олександра Володимирівна Державна установа «Інститут ядерної медицини та променевої діагностики Національної академії медичних наук України», консультативно-поліклінічний відділ;

вул. Платона Майбороди, буд. 32, м. Київ, Україна, 04050;

e-mail: irinadykan@gmail.com al.semenova@i.ua

(С) Семьонова О.В., Мироняк Л.А., Глазовська І.І., Іванова М.Ф., Красюк O.A., 2021

\section{PEЗЮME}

Актуальність. Актуальність проблеми церебральної хвороби малих судин (ЦХМС) у сучасній неврології розглядається, головним чином, з точки зору розвитку судинної деменції та ранньої діагностики хвороби Альцгеймера. Мінімальні зміни МРТзображень й невиразні когнітивні розлади при ЦХМС типу спорадичної неамілоїдної мікроангіопатії (CHАMA) тривають довгий час, аж доки не маніфестують гострим порушенням мозкового кровообігу та/або значним ментальним дефріцитом. Утім, досі не сфрормульовано клініко-нейровізуалізаційних критеріїв ранньої діагностики хвороби та не з'ясовано характер кореляційних зв'язків між показниками нейропсихологічних і мультипараметричних МРТ-досліджень.

Мета роботи - розробити критерії ранньої діагностики церебральної хвороби малих судин типу CHАMA у пацієнтів середнього віку із застосуванням високопільної мультипараметричної МРТ і нейропсихологічних досліджень.

Матеріали та методи. Обстежено 34 пацієнти середнього віку $(52,5 \pm 10,8$ р.) 3 артеріальною гіпертензією (АГ) 1-2 ст., І-ІІ ст. і ЦХМС (жінок - 11 (32,4\%), чоловіків - $23(67,6 \%))$. Контрольна група (19 практично здорових осіб) ідентична за віком, гендерною належністю і загальною тривалістю освіти. МРТ (ЗТ) виконано в режимах: $\mathrm{T}_{1-2} \mathrm{WI}$, DWI, 3D Brain FLAIR SHC, 3D tra, VEN BOLD, DTI medium iso SENSE. Нейропсихологічні дослідження проводили із застосуванням опитувальника МоCA з оцінкою доменів EIS, VIS, AIS, LIS, MIS, OIS.

Результати та їх обговорення. Розроблено та впроваджено до клінічної практики модифріковану бальну систему визначення тягаря ранньої хвороби малих судин (ТЦХМСр). Серед ранніх візуальних МРТ маркерів домінувало розширення периваскулярних просторів - $27(79,4 \%)$ спостережень. Незначне збільшення ¿ТЦХМСр до 6-7 балів виявлено у $10(29,4 \%)$ пацієнтів. Віковій нормі (0-4 бали) відповідали показники $\Sigma$ ТЦХМСр 23 із $34(67,6 \%)$ досліджуваних основної групи. Додаткові докази про наявність хвороби отримано при DTI MPT. Найсуттєвіше зменшення FA зафіксовано у волокнах поясів $(\Delta$ : до $-31,4 \%)$ і семіовальних центрах ( $\Delta$ : до - 33,6\%), найбільше зростання MD - у гачкуватих пучках ( $\Delta$ : до $24,4 \%)$; 
правих префронтальних, орбітофронтальних і тім'яних ділянках ( $\Delta$ : до 28,0\%) За шкалою МоСА помірні когнітивні порушення виявлено у 29 з 34 (85,3\%) хворих із достовірним зменшенням суми балів у доменах EIS, VIS, LIS і AIS $(p<0,001)$. Встановлено, що виразність ранніх клінічних проявів ЦХМС (неамнестичні полідоменні помірні порушення уваги, мовлення, візуально-просторової та виконавчої когнітивних фуннкцій) перебувають у помірному/помітному кореляційному зв'язку із показниками TXMCp, коефіцієнта MD (позитивний) і FA (негативний).

Висновки. Визначено ранні візуальні ознаки асоційованої з артеріальною гіпертензією ЦХМС: розширені периваскулярні простори, гіперінтенсивність перивентрикулярної глибокої білої речовини головного мозку, зменшення на 9-33,6\% коефріцієнта FA та зростання на $20,8 \%-28,0 \%$ MD. Доведено наявність помірних кореляційних зв'язків між показниками нейропсихологічних і нейровізуалізаційних досліджень.

\section{Для цитування:}

Семьонова О.В., Мироняк Л.А., Глазовська І.І., Іванова М.Ф., Красюк О.А. Візуальні та довізуальні МРТкритерії ранньої діагностики церебральної хвороби малих судин у пацієнтів середнього віку: клініконейровізуалізаційні кореляції. Український радіологічний та онкологічний журнал. 2021. Т. 29. № 3. С. 89-100. DOI: https://doi.org/10.46879/ukroj.3.2021.89-100

Key words:

papillary cancer, thyroid, radioiodine resistant metastases, cytological signs, oxyphilic changes, cystic changes.

\section{For correspondence:}

\section{Semonova Olexandra Volodymyrivna} State institution «Institute Nuclear Medicine and Diagnostic Radiology of National Academy of Medical Science of Ukraine», consultation out patient;

32, Platona Mayiborody Str., Kyiv, Ukraine, 04050;

e-mail: al.semenova@i.ua

(c) Semonova O.V., Myronyak L.A., Glazovska I.I., Ivanova M.F., Krasyuk O.A., 2021

\section{ABSTRACT}

Background. The urgency of cerebral small vessel disease (CSVD) in modern neurology is considered mainly in terms of the development of vascular dementia and early diagnosis of Alzheimer's disease. Minimal changes in MRI images and indistinct cognitive disorders in SNAMA-type CSVD (sporadic non-amyloid microangiopathy) last for a long time until they manifest as acute cerebrovascular disorders and/or significant mental deficits. However, clinical and neuroimaging criteria for early diagnosis of the disease have not been established yet, and the nature of the correlations between the indicators of neuropsychological and multiparametric MRI studies has not been clarified.

Purpose - to develop criteria for early diagnosis of SNAMA cerebrovascular disease in middle-aged patients using neuropsychological studies and high-field multiparametric MRI. Materials and methods. The study enrolled 34 middle-aged patients $(52.5 \pm 10.8)$ with hypertension of stage 1-2, stage I-II and CSVD (women - $11(32.4 \%)$, men - $23(67.6 \%)$ ). The control group (19 healthy individuals) was identical in age, gender and total duration of education. MRI (3T) was performed in the following modes: T1-2WI, DWI, 3D Brain FLAIR SHC, 3D tra, VEN BOLD, DTI medium iso SENSE. Neuropsychological studies were performed using the MoSA questionnaire evaluating the EIS, VIS, AIS, LIS, MIS, OIS domains.

Results and discussion. We developed and introduced a modified scoring system for determining the severity of the burden of cerebral small vessels disease (BcSVDearly) in clinical practice. Among the early visual MRI markers, the expansion of the perivascular spaces was dominated in $27(79.4 \%)$ of participants. A minor increase in $\sum$ BcSVDearly to 6-7 points was found in $10(29.4 \%)$ patients. The age norm (0-4 points) corresponded to the indicators of $\sum$ BcSVDearly 23 out of $34(67.6 \%)$ in the main group. Additional evidence of the disease was obtained by DTI MRI. The most significant decrease in FA was recorded in belt fibers ( $\Delta$ : up to $-31.4 \%$ ) and semioval centers ( $\Delta$ : up to $-33.6 \%$ ), the largest increase in MD was recorded in hooked bundles ( $\Delta$ : up to $24.4 \%)$; right prefrontal, orbitofrontal and parietal areas ( $\Delta$ up to $28.0 \%$ ). According to the MoSA scale, moderate cognitive impairment was detected in 29 of 34 (85.3\%) patients with a significant decrease in scores in the domains of EIS, VIS, LIS and AIS $(p<0.001)$. The severity of early clinical manifestations of CSVD (non-amnestic polydomain moderate disorders of attention, speech, visual-spatial and executive cognitive functions) has been found to be moderately / markedly correlated with THMS, MD (positive) and FA (negative).

Conclusions. We determined early visual signs of CSVD associated with arterial hypertension: dilated perivascular spaces, hyperintensity of the periventricular deep white matter of the brain, decrease by $9-33.6 \%$ of FA coefficient and increase by $20.8 \%-28.0 \%$ MD. Moderate correlations between neuropsychological and neuroimaging studies have been demonstrated.

For citation:

Semonova OV, Myronyak LA, Glazovska II, Ivanova MF, Krasyuk OA. Visual and previsual MRI-criteria for early diagnosis of cerebral small vessels disease in middle-aged patients: clinical and neuroimaging correlations. Ukrainian journal of radiology and oncology. 2021;29(3):89-100. DOI: https://doi.org/10.46879/ukroj.3.2021.89-100

\section{Зв'язок роботи 3 науковими програмами,} планами і темами

\section{Relationship with academic programs,} plans and themes
Стаття $є$ фрагментом спільної науково-дослідної роботи Державної установи «Інститут ядерної медицини та променевої діагностики Національної академії медичних наук України» та кафедри неврології №1 Національного університету
The paper is a fragment of the collaborative research project of State Institution «Institute of Nuclear Medicine and Diagnostic Radiology of National Academy of Medical Science of Ukraine» and Neurology Department No 1 of Shupyk National Healthcare 
охорони здоров'я України ім. П.Л. Шупика «Вікові особливості когнітивних порушень при хворобі малих судин головного мозку», номер державної реєстрації 0118U100253, прикладна, термін виконання: 2018-2022 рр., науковий керівник завідувач кафедри неврології №1, доктор медичних наук, профресор Головченко Ю.І.
University of Ukraine which is "Age peculiarities of cognitive disorders in cerebral small vessels disease», state registration No: 0118U100253, applied, period for performance: 2018 - 2022, led by Head of Neurology Department No 1, Doctor of Medical Sciences, Professor Yu.O. Holovchenko.

\section{ВСТУП}

Актуальність проблеми церебральної хвороби малих судин (ЦХМС, Cerebral Small Vessels Disease-cSVD) у сучасній неврології розглядається, головним чином, з точки зору розвитку судинної деменції $[1,2]$ та ранньої діагностики хвороби Альцгеймера [3]. Втім, мінімальні зміни МРТ-зображень й невиразні когнітивні розлади при ЦХМС типу СНАМА (спорадична неамілоїдна мікроангіопатія, sporadic cerebral non-amyloid microangiopathy SCNAMA), тривають довгий час, аж доки не маніфестують гострим порушенням мозкового кровообігу та/або значним ментальним дефіцитом [4]. Оскільки цей патогенетичний різновид церебральної хвороби малих судин асоційований із артеріальною гіпертензією (АГ, Arterial Hypertension - AH), основні зусилля в лікуванні пацієнтів сконцентровані на досягненні нормативних параметрів артеріального тиску, залишаючи поза увагою м'які когнітивні розлади, хронічну церебральну ішемію та втрату регулярної структури глибокої білої речовини головного мозку [4, 5].

Вдосконалення нейровізуалізаційних технологій, передусім завдяки запровадженню високопільної (3Т) та дифузійно-тензорної (DTI) мультипараметричної МРТ, відкрило нові перспективи вчасної діагностики CHAMA [6]. У цій сфері незаперечним досягненням визнано консенсус щодо переліку, визначень та єдиної термінології МРТ-ознак церебральної хвороби малих судин [7]. Не менш важливими виявились розроблені на додаток до малопридатної для оцінки початкових проявів захворювання Fazekas Scale напівкількісні способи визначення тягаря ЦХМС (ТЦХМС, the burden of cerebral small vessels disease - BcSVD) [8, 9].

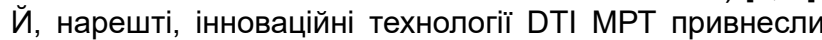
до клінічної практики дійсно кількісну оцінку структурних змін білої речовини головного мозку (БРГМ, White Matter - WM) за допомогою коефріцієнта фракційної анізотропії (FA) та середнього коефіцієнта дифузії (MD) [9]. На цей час сформувалась досить представницька група дослідників, котрі визнають показники ізотропної та анізотропної дифузії як довізуальні маркери патології БРГМ [9, 10, 11].

Попри існування численних наукових публікацій стосовно проблеми ЦХМС, залишаються нез'ясованими деякі позиції.

По-перше, не сформульовані клініко-нейровізуалізаційні критерії ранньої діагностики ЦХМС типу СНАМА та відсутні напівкількісні шкали для обчислення тягаря ранньої ЦХМС (ТЦХMCp, BcSVDearly).

По-друге, у пацієнтів із ЦХМС середнього віку не визначені характер і сила кореляційних зв'язків між показниками нейропсихологічних і мультипараметричних МРТ-досліджень.

Мета роботи - розробити критерії ранньої діагностики церебральної хвороби малих судин типу CHAMA у пацієнтів середнього віку із застосуванням високопільної мультипараметричної МРТ і нейропсихологічних досліджень.

\section{INTRODUCTION}

The urgency of Cerebral Small Vessels Disease (cSVD) in modern neurology is considered mainly in terms of the development of vascular dementia [1, 2] and early diagnosis of Alzheimer's disease [3]. However, minimal changes in MRI images and vague cognitive impairment in CSVD of SNAMA-type (sporadic cerebral non-amyloid microangiopathy - SCNAMA) persist for a long time until acute cerebral palsy and cerebral hemorrhage are manifested [4]. Since this pathogenetic form of cerebrovascular disease is associated with arterial hypertension $(\mathrm{AH})$, the main efforts in the treatment of patients are focused on achieving the normative parameters of blood pressure, ignoring mild cognitive disorders, chronic cerebral dysfunction and loss of the regular structure of the deep white brain matter $[4,5]$.

Improvements in neuroimaging technologies, mainly through the introduction of high-field (3T) and diffusiontensor (DTI) multiparametric MRI, have opened up new prospects for timely diagnosis of SNAMA [6]. In this area, the consensus on the list, definitions and common terminology of MRI signs of cerebral small vessel disease is recognized as an indisputable achievement [7]. No less important were the semi-quantitative methods for determining the burden of CHMS, developed in addition to the Fazekas Scale, which was not very suitable for assessing the initial manifestations of the CSVD burden (the burden of cerebral small vessels disease - BcSVD) [8, 9]. Finally, innovative DTI MRI technologies have introduced into clinical practice a truly quantitative assessment of structural changes in the white matter of the brain (WM) using the fractional anisotropy factor (FA) and the average diffusion coefficient (MD) [9]. At this time, a sufficiently representative group of researchers has been formed, who recognize the indicators of isotropic and anisotropic diffusion as previsual markers of WM pathology $[9,10,11]$.

Despite the existence of numerous scientific contributions on the problem of CSVD, a number of positions remain unclear.

First, there are no formulated clinical and neuroimaging criteria for early diagnosis of CSVD of SNAMA type and there are no semi-quantitative scales for calculating the burden of early cSVD (BcSVDearly). Second, in middleaged patients with CSVD, the nature and strength of the correlations between neuropsychological and multiparametric MRI have not been determined.

Purpose - to develop criteria for early diagnosis of cSVD of SNAMA type in middle-aged patients using neuropsychological studies and high-field multiparametric MRI. 


\section{МАТЕРІАЛИ ТА МЕТОДИ ДОСЛІДЖЕННЯ}

До основної когорти досліджуваних середнього віку (СВгр.) залучено 34 пацієнти з АГ 1-2 ст., І-ІІ ст. і церебральною хворобою малих судин типу СНАMA, в тому числі: жінок - 11 (32,4\%), чоловіків - 23 (67,6\%). Критерії виключення з дослідження: вогнищева неврологічна симптоматика, гемодинамічно значимий стеноз судин каротидного басейну, церебральні інсульти, пухлини та наслідки значних травматичних пошкоджень головного мозку, демієлінізуючі захворювання, хвороба Альцгеймера, деменція, протипоказання до МРТ.

Контрольну групу (КГСВ) склали 19 спостережень практично здорових осіб (6 (32,6\%) жінок та 13 (67,4\%) чоловіків. За віком $(52,5 \pm 10,8$ р. та $50,4 \pm 5,6$ р.), загальною тривалістю освіти $(11,31 \pm 2,16$ р. та $11,78 \pm 3,29$ р.) та співвідношенням середня/середня спеціальна/вища освіта $(5,9 \% / 32,4 \% / 61,7 \%$ та $5,4 \% / 36,8 \% / 57,8)$ СВгр. і КГСВ були практично ідентичними.

Мультипараметричну МРТ проводили на томографрі Ingenia («Philips») з індукцією магнітного поля 3Т в режимах: $T_{2}$ WI, DWI (b 1000), 3D Brain FLAIR SHC, T,WI, 3D tra, VEN BOLD, DTI medium iso SENSE. Постпроцесинг DTI MPT здійснювали за допомогою SOFTWARE «IntelliSpacePortal MR Fibertrac» із мультипланарними реконструкціями.

$\mathrm{Ha} \mathrm{T}_{1} \mathrm{WI}, \mathrm{T}_{2} \mathrm{WI}, 3 \mathrm{D}$ Brain FLAIR i VEN BOLD MPT зображеннях визначали маркери церебральної хвороби малих судин [11, 12]: розширені периваскулярні простори (РПВП) (enlarged perivascular spaces - EPVS); перивентрикулярна гіперінтенсивність глибокої білої речовини (ПВГІБР) (periventricular hyperintensity of white matter - PVWMH); гіперінтенсивність глибокої білої речовини головного мозку (ГІГБРГМ) (white matter hyperintensity - WMH), лакунарні інфаркти (ЛІ) (lacunar infarction - LI), церебральні мікрокрововиливи (ЦМК) (cerebral microbleed - CMBs).

Визначення коефіцієнта фрракційної анізотропії (FA) та середнього коефіцієнта дифузії (MD) здійснювали в основних асоціативних та комісуральних провідних шляхах: верхніх поздовжніх пучках (fasciculus longitudinalis superior - SLF), поясах (cingulum - C), гачкуватих пучках (fasciculus uncinatus - FU), нижніх поздовжніх пучках (fasciculus longitudinalis inferior - SLF), коліні (genu corporis callosum - GCC) і валику мозолистого тіла (splenium corporis callosum - SCC). Для інтегральної оцінки структурованості глибокої білої речовини головного мозку (ГБРГМ) додатково обрані «зони інтересу» ROI в префронтальних (prefrontal - PF), орбітофронтальних (orbitofrontal - OF), тім'яних (parietal - P), потиличних (occipital - Oc), передніх перивентрикулярних ділянках (periventricular anterior - Pvant.) і семіовальних центрах (semioval centers - SOC).

Для визначення тяжкості ранньої хвороби малих судин (ТЦХMCp, BcSVDearly) застосовано розроблену нами модифіковану бальну систему [14].

Нейропсихологічні дослідження проводили із застосуванням опитувальника МоCA (Montreal Cognitive Assessment) у перегляді N. Carson, L. Leach, K.J. Murphy, 2018 [13]. Обчислювали сумарний бал ¿MoCA та бальні оцінки в когнітивних доменах: орієнтації (orientation - OIS), уваги (attention - AIS), мови (language - LIS), візуально-просторової функції (visuospatial function - VIS), пам'яті (memory - MIS) та виконавчої функції (executive function - EIS).

\section{MATERIALS AND METHODS}

The main cohort of middle-aged subjects (MA) involved 34 patients with hypertension of stage 1-2, I-II stage and cerebral disease of small vessels of SNAMA type, including: women - 11 (32.4\%), men - 23 (67.6\%). Exclusion criteria from the study: focal neurological symptoms, hemodynamically significant stenosis of the vessels of the carotid basin, cerebral strokes, tumors and the consequences of significant traumatic brain injury, demyelinating diseases, Alzheimer's disease, dementia, contraindications to MRI.

The control group (CG) consisted of 19 observations of almost healthy individuals (6 (32.6\%) women and $13(67.4 \%)$ men, aged $52.5 \pm 10.8$ years and $50.4 \pm 5.6$ years $)$, the total duration of education $(11.31 \pm 2.16$ years and $11.78 \pm 3.29$ years) and the ratio of secondary / secondary special / higher education $(5.9 \% / 32.4 \% / 61.7 \%$ and $5.4 \% / 36.8 \%$ / 57.8) MA and CG were almost identical.

Multiparametric MRI was performed on Ingenia (Philips) tomograph with $3 \mathrm{~T}$ magnetic field induction in the following modes: $T_{2}$ WI, DWI (b 1000), 3D Brain FLAIR SHC, $\mathrm{T}_{1} \mathrm{WI}, 3 \mathrm{D}$ tra, VEN BOLD, DTI medium iso SENSE. Postprocessing of DTI MRI was performed by means of SOFTWARE «IntelliSpacePortal MR Fibertrac» with multiplanar reconstructions.

The cSVD markers were determined on $T_{1} W I, T_{2} W I$, 3D Brain FLAIR and VEN BOLD MRI images [11, 12]: enlarged perivascular spaces (EPVS); periventricular white matter hypersensitivity (PVWMH); white matter hyperintensity (WMH), lacunar infarction (LI), cerebral microbleed (CMBs).

The fractional anisotropy coefficient (FA) and the average diffusion coefficient (MD) were assessed in the main associative and commissural conduction pathways: upper longitudinal bundles (fasciculus longitudinalis superior - SLF), cingula (cingulum - C), hooked bundles (fasciculus uncinatus - FU), lower longitudinal bundles (fasciculus longitudinalis inferior - SLF), genu (genu corporis callosum - GCC), and corpus callosum (splenium corporis callosum - SCC). For an integrated assessment of the structure of the deep white matter of the brain (DWBM), the "areas of interest» - ROI in prefrontal (PF), orbitofrontal (orbitofrontal - OF), parietal (parietal - P), occipital (occipital - Oc), anterior periventricular areas (periventricular anterior - Pvant.) and semioval centers (semioval centers - SOC) were additionally selected.

To determine the burden of early small vessel disease (BcSVDearly) we developed a modified scoring system [14].

Neuropsychological studies were performed using the MoSA questionnaire (Montreal Cognitive Assessment) by N. Carson, L. Leach, K.J. Murphy, 2018 [13]. We calculated the total score $\sum \mathrm{MoCA}$ and scores in the cognitive domains: orientation (OIS), attention (AIS), language (LIS), visuospatial function (VIS), memory (MIS) and executive function (EIS).

Microsoft $^{\circledR}$ Excel 2002, StatSoft, Inc. (2011) software was used for statistical processing of the obtained data. STATISTICA (data analysis software system), version 10 www.statsoft.com. Since the distribution law of indicators differed from the normal one ( $p<0.05$ according to the Shapiro-Wilk criterion), the median value (Me) and the interquartile range $\left(Q_{1}-Q_{\text {III }}\right)$ were calculated for data presentation. The Mann-Whitney test was used for comparison. Correlations between the parameters were 
Для статистичної обробки отриманих даних використовували програмне забезпечення Microsoft $^{\circledR}$ Excel 2002, StatSoft, Inc. (2011). STATISTICA (data analysis software system), version 10 www.statsoft.com. Оскільки закон розподілу показників відрізнявся від нормального ( $<<0,05$ за критерієм Шапіро-Вілка), для представлення даних розраховано медіанне значення (Me) та міжквартильний інтервал $\left(Q_{1}-Q_{11}\right)$. Для проведення порівняння використано критерій Манна-Уїтні. Кореляційні зв'язки між параметрами визначали через розрахунок коефіцієнта біваріантної рангової кореляції Спірмена (rs). Відповідно до шкали Чеддока: при rs = 0 - зв'язок відсутній; від 0,1 до 0,29 - слабкий; від 0,3 до 0,49 - помірний; від 0,5 до 0,69 - помітний; від 0,7 до 0,9 - високий. Коефріцієнт кореляції оцінювали як достовірний при $\mathrm{p} \leq 0,05$.

Дослідження проведені у відповідності до стандартів «Належної клінічної практики» (Good Clinical Practice) і принципів Гельсінської Декларації. Учасники дослідження були ознайомлені з метою й основними положеннями дослідження та підписали письмово оформлену згоду на участь у ньому. Протокол дослідження схвалено комітетами 3 медичної етики Державної установи «Інститут ядерної медицини та променевої діагностики Національної академії медичних наук України» та Національного університету охорони здоров'я України ім. П.Л. Шупика.

\section{РЕЗУЛЬТАТИ ТА ЇХ ОБГОВОРЕННЯ}

Діагностика й моніторинг перебігу асоційованої 3 АГ ЦХМС передбачають порівняння результатів нейропсихологічнихтанейровізуалізаційнихдосліджень [1,2,4]. У клінічній неврології з цією метою застосовуються когнітивні шкали [13], в радіології - напівкількісні покажчики тягаря хвороби малих судин (ТЦХМС, the Burden of Cerebral Small Vessels Disease - BcSVD) [8].

Серед ментальних тестів існує адекватний для ранніх м'яких когнітивних порушень (mild cognitive impairment) Монреальський опитувальник МoCA [13]. Натомість, напівкількісна оцінка візуальних МРТ ознак ранньої хвороби малих судин (Early of Cerebral Small Vessels Disease - CSVDearly) лишається проблематичною, бо існуючі шкали ТЦХМС призначені для більш пізніх її стадій $[7,8,11,14]$.

Оцінка ранніх візуальних МРТ-ознак ЦХМС у пацієнтів середнього віку констатує достовірне збільшення, порівняно з контрольними величинами, усіх показників (табл. 1), окрім індексу Еванса $\left(Q_{1}-Q_{\text {III }}: 0,23-0,25\right.$ проти $0,2-0,25, p=0,549$, що свідчить про відсутність атрофрічних змін БРГМ. Наслідки лакунарного інфаркту

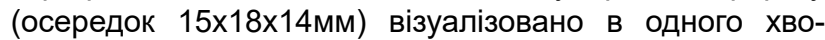
рого. Інтрацеребральних крововиливів в основній групі СВ не виявлено.

Серед ранніх візуальних МРТ маркерів домінували РПВП - 27 (79,4\%) спостережень. 3 них, за шкалою ТЦХМСр, у 2 бали оцінено 10 (29,4\%) випадків; 17 (50,0\%) - у 3 бали. В 20,6\% (7) обстежених основної групи периваскулярні простори відповідали критеріям норми.

Незмінені перивентрикулярні ділянки БРГМ візуалізовані у $24(70,6 \%)$ хворих. У $6(17,6 \%)$ пацієнтів по контуру бокових шлуночків спостерігали помірне гіперінтенсивне «halo» товщиною до 5 мм (2 бали ТЦХМСp). Більші за 7 мм ПВГІБРГМ з нерівними контурами та поширенням на глибокі відділи білої речовини (3 бали ТЦХМСр) виявлено в 4 (11,8\%) випадках. determined by calculating Spearman's bivariate rank correlation coefficient ( $r s$ ). According to the Chaddock scale: at rs $=0$ - no connection; from 0.1 to 0.29 - weak; from 0.3 to 0.49 - moderate; from 0.5 to 0.69 - noticeable; from 0.7 to $0.9-$ high. The correlation coefficient was evaluated as significant at $p \leq 0.05$.

The study was carried out in accordance with the standards of Good Clinical Practice and the principles of the Helsinki Declaration. The participants of the study were informed about the purpose and the main provisions of the study and signed a written consent to participate in it. The protocol was approved by the committees of medical ethics of State institution «Institute Nuclear Medicine and Diagnostic Radiology of National Academy of Medical Science of Ukraine» and Shupyk National Healthcare University of Ukraine.

\section{RESULTS AND DISCUSSION}

In order to diagnose and investigate the hypertensionassociated cSVD the clinicians have to compare the results of neuropsychological and neuroimaging observations $[1,2,4]$. In Clinical Neurology stagnating cognitive scales are used [13], while in Radiology - the Burden of Cerebral Small Vessels Disease (BcSVD) [8].

Among the mental tests, there is the Montreal MoCA questionnaire, which is appropriate for early mild cognitive impairment [13]. Instead, the semi-quantitative assessment of visual MRI signs of Early Cerebral Small Vessels Disease (CSVDearly) remains problematic because existing CSVD scales are intended for later stages [7, 8, 11, 14].

Evaluation of early visual MRI signs of CSVD in middleaged patients finds a significant increase, compared with control values, of all indicators (Table 1), except for the Evans index $\left(Q_{1}-Q_{1 \mid 1}: 0.23-0.25\right.$ vs. $0 .-0.25, p=0.549$, indicating the absence of atrophic WM (white matter) changes. The consequences of lacunar infarction $(15 \times 18 \times 14 \mathrm{~mm})$ were visualized in one patient. Intracerebral hemorrhage in the MA group was not detected.

Among the early visual MRI markers, EPVS dominated $-27(79.4 \%)$ observations. Out of these, according to BcSVDearly scale, $10(29.4 \%)$ cases received 2 points; $17(50.0 \%)-3$ points. In $20.6 \%$ (7) of the patients of the main group, perivascular spaces met the normal criteria.

Unchanged periventricular areas of WM were visualized in $24(70.6 \%)$ patients. In $6(17.6 \%)$ patients, along the contour of the lateral ventricles, moderate hyperintensive «halo» up to $5 \mathrm{~mm}$ in width (2 points according to BcSVDearly scale) was observed. More than $7 \mathrm{~mm}$ PVWMH (periventricular white matter hyperintensity) with uneven contours and spread to deep parts of white matter (3 points according to BcSVDearly scale) were recorded in $4(11.8 \%)$ cases.

The number and size of DWMH (deep white matter hyperintensity) foci met the average criteria in middle- 
Таблиця 1. Ранні МРТ-візуальні маркери ЦХМС у контрольній та основній групах Table 1. Early MRI-visual markers of CSVD in the control and main groups

\begin{tabular}{|c|c|c|c|c|c|}
\hline \multirow[t]{2}{*}{$\begin{array}{l}\text { Показник } \\
\text { Categorie }\end{array}$} & \multicolumn{2}{|c|}{$\begin{array}{c}\text { Контрольна група середнього віку } \\
\text { CG middle age } \\
(n=19)\end{array}$} & \multicolumn{2}{|c|}{$\begin{array}{l}\text { Група середнього віку } \\
\text { MG middle age } \\
(n=34)\end{array}$} & \multirow[t]{2}{*}{ p } \\
\hline & $\mathrm{Me}$ & $Q_{1}-Q_{111}$ & Me & $Q_{1}-Q_{111}$ & \\
\hline Evans Index & 0,23 & $0,2-0,25$ & 0,24 & $0,23-0,25$ & 0,549 \\
\hline Fazekas scale & 0 & $0-0,75$ & 1 & $1-2$ & $<0,001$ \\
\hline $\begin{array}{l}\text { ТЦХМCp: РПВП } \\
\text { BcSVDearly: EPVS }\end{array}$ & 1 & $1-1$ & 2,5 & $2-3$ & $<0,001$ \\
\hline $\begin{array}{l}\text { TЦХМСp: ГІПВГБРГМ } \\
\text { BcSVDearly: РVWMH }\end{array}$ & 1 & $0-1$ & 1 & $1-2$ & $<0,001$ \\
\hline $\begin{array}{l}\text { TЦХМCp: ГІГБРГМ } \\
\text { BcSVDearly: WMH }\end{array}$ & 0 & $0-0$ & 1 & $0-1$ & $<0,001$ \\
\hline $\begin{array}{l}\text { TЦХМCp: } \sum \\
\text { BcSVDearly: } \Sigma\end{array}$ & 2 & $1-2$ & 4 & $3-6$ & $<0,001$ \\
\hline
\end{tabular}

\section{Примітки:}

p - порівняння основної і контрольної груп обстежених середнього віку

Notes:

$p$ - comparison of the main and control groups of the surveyed middle-aged

Кількість та розмір вогнищ ГІГБРГМ відповідали критеріям норми для осіб середнього віку в 24 (70,6\%) спостереженнях. Множинні точкові фокуси до 10 мм у діаметрі (2 бали ТЦХМС) та множинні вогнища, у тому числі й у базальних гангліях, із тенденцією до консолідації (3 бали ТЦХМСр) виявлено у 3 (8,8\%) і 6 (17,6\%) пацієнтів, відповідно. Поширені консолідовані фокуси ГІГБРГМ (4 бали ТЦХМСр) візуалізовано в одного хворого.

Незначне збільшення виявлено в 10 (29,4\%) спостереженнях. Наявність залишкового осередку після перенесеного лакунарного інфаркту в одного пацієнта підвищила сумарний бал до 15. Тим часом, віковій нормі (04 бали) відповідали показники टТЦХМСр 23 із 34 (67,6\%) досліджуваних основної групи, що потребувало додаткових доказів про наявність спорадичної неамілоїдної мікроангіопатії.

До вирішення цього завдання були залучені дослідження даних дифузійно-тензорних послідовностей МРТ. Закономірності змін коефіцієнтів анізотропної (FA) та ізотропної (MD) дифузії (табл. 2 - 5) свідчили про те, що початкова патологічна перебудова структури ГБРГМ має мозаїчний та дифузний характер.

Попри достовірно ( $\mathrm{p}<0,001)$ нижчі коефіцієнти FA (табл. 2, 3) в усіх асоціативних провідних трактах і обраних для вимірювання ROI, найсуттєвіші відмін ності зафріксовані у волокнах поясу (Mе - ПП: $\Delta=-23,9 \%$, ЛП: $\Delta=-31,4 \%)$. Відносне зменшення фракційної анізотропії в решті провідних шляхів коливалось у межах: $-19,4-(-13,8) \%$.

Коефіцієнти FA в обраних зонах інтересу (ROI) ГБРГМ були зменшені В діапазоні 9,5-33,6\%. Найбільш значні зміни були притаманні ПФД (ПП: $\Delta=-21,5 \%$, ЛП: $\Delta=-23,2 \%)$, ППВД (ПП: $\Delta=-19,4 \%$, лП: $\Delta=-20,1 \%)$ і СОЦ (ПП: $\Delta=-25,6 \%$, ЛП: $\Delta=-33,6 \%$ ).

Ізотропна дифузія (MD) у БРГМ на тлі ЦХМС змінилась у бік зростання (табл. 4, 5). Найсуттєвішим воно було в ГП (ПП: $\Delta=24,4 \%$, ЛП: $\Delta=23,8 \%)$; правих ПФД $(\Delta=20,9 \%)$, ОФД $(\Delta=20,8 \%)$ і ТД $(\Delta=28,0 \%)$. aged people in $24(70.6 \%)$ cases. Multiple point foci up to $10 \mathrm{~mm}$ in diameter (2 points according to BcSVD scale) and multiple foci, including in the basal ganglia, with a tendency to consolidation (3 points according to BcSVDearly scale) were found in $3(8.8 \%)$ and $6(17,6 \%)$ of patients, respectively. Common consolidated foci of DWMH (4 points according to BcSVDearly scale) were visualized in one patient.

A minor increase in $\sum$ BcSVDearly up to 6-7 points was detected in $10(29.4 \%)$ observations. The presence of residual foci after lacunar infarction in one patient increased the total score to 15. Meanwhile, the age norm (0-4 points) corresponded to the indicators of $\sum$ BcSVDearly 23 of $34(67.6 \%)$ of the main group, which required additional evidence of sporadic non-amyloid microangiopathy.

Studies focused on the data of diffusion-tensor sequences of MRI were involved in solving this problem. Regularities of changes in the coefficients of anisotropic (FA) and isotropic (MD) diffusion (Tables 2-5) indicated that the initial pathological rearrangement of the structure of $\mathrm{WMH}$ was characterized by a mosaic and diffuse character.

Despite significantly $(p<0.001)$ lower FA coefficients (Tables 2, 3) in all associative conductive pathways and ROI selected for measurement, the most significant differences were recorded in cingulum fibers (Me $-\mathrm{RH}$ (right hemisphere): $\Delta=-23.9 \%$, LH (left hemisphere): $\Delta=-31.4 \%)$. The relative decrease in fractional anisotropy in the other leading pathways ranged within: $-19.4--13.8 \%$.

The coefficients of FA in selected areas of interest (ROI) WMH were reduced within the range of $9.5-33.6 \%$. The most significant changes were inherent in $\mathrm{PF}$ (RH (right hemisphere): $\Delta=-21.5 \%, \mathrm{LH}: \Delta=-23.2 \%$ ), PVant (LH: $\Delta=-19.4 \%, \mathrm{LH}: \Delta=-20.1 \%$ ) and SOC $(\mathrm{RH}: \Delta=-25.6 \%$, LH: $\Delta=-33.6 \%)$.

Isotropic diffusion (MD) in WM accosiated with CSVD (cerebral small vessels disease) changed in the direction of growth (Tables 4, 5). It was most significant in FU (RH: $\Delta=24.4 \%, \mathrm{LH}: \Delta=23.8 \%)$; right PF $(\Delta=20.9 \%)$, OF $(\Delta=20.8 \%)$ and $\mathrm{P}(\Delta=28.0 \%)$. 
Таблиця 2. FA провідних шляхів головного мозку в контрольній і основній групах Table 2. FA of cerebral fiber tracts in the control and main groups

\begin{tabular}{|c|c|c|c|c|c|}
\hline \multirow[t]{2}{*}{$\begin{array}{l}\text { Показник } \\
\text { Categorie }\end{array}$} & \multicolumn{2}{|c|}{$\begin{array}{c}\text { Контрольна група } \\
\text { Control group } \\
(n=19)\end{array}$} & \multicolumn{2}{|c|}{$\begin{array}{l}\text { Основна група } \\
\text { Main group } \\
(n=34)\end{array}$} & \multirow[t]{2}{*}{$\mathbf{p}$} \\
\hline & Me & $Q_{1}-Q_{111}$ & Me & $Q_{1}-Q_{I I I}$ & \\
\hline \multicolumn{6}{|c|}{ FA права півкуля / FA right hemisphere } \\
\hline ВПП /SLF & 0,499 & $0,493-0,502$ & 0,429 & $0,409-0,438$ & $<0,001$ \\
\hline$\Pi / C$ & 0,532 & $0,499-0,542$ & 0,405 & $0,385-0,424$ & $<0,001$ \\
\hline ГП/FU & 0,485 & $0,482-0,494$ & 0,415 & $0,392-0,427$ & $<0,001$ \\
\hline $\mathrm{H \Pi \Pi /ILF}$ & 0,529 & $0,511-0,536$ & 0,447 & $0,434-0,482$ & $<0,001$ \\
\hline \multicolumn{6}{|c|}{ FA ліва півкуля / FA left hemisphere } \\
\hline ВПП /SLF & 0,509 & $0,499-0,516$ & 0,421 & $0,411-0,434$ & $<0,001$ \\
\hline$\Pi / C$ & 0,592 & $0,567-0,599$ & 0,406 & $0,372-0,429$ & $<0,001$ \\
\hline ГП/FU & 0,499 & $0,497-0,501$ & 0,415 & $0,405-0,437$ & $<0,001$ \\
\hline HПП/ILF & 0,525 & $0,514-0,530$ & 0,446 & $0,433-0,459$ & $<0,001$ \\
\hline \multicolumn{6}{|c|}{ FA MT / FA CC } \\
\hline KMT/GCC & 0,558 & $0,556-0,567$ & 0,450 & $0,443-0,476$ & $<0,001$ \\
\hline BMT/SCC & 0,550 & $0,544-0,562$ & 0,474 & $0,462-0,487$ & $<0,001$ \\
\hline
\end{tabular}

\section{Примітки:}

Закон розподілу показників відрізнявся від нормального ( $p<0,05$ за критерієм Шапіро-Вілка), для представлення даних розраховано медіанне значення (Мe) та міжквартильний інтервал $\left(Q_{1}-Q_{\| I}\right)$. Для проведення порівняння використано критерій Манна-Уїтні.

Notes:

The law of distribution of indicators differed from normal ( $p<0.05$ according to the Shapiro-Wilk criterion), the median value (Me) and the interquartile range $\left(Q_{1}-Q_{I I I}\right)$ were calculated for data presentation. The Mann-Whitney test was used for comparison.

Таблиця 3. FA ROI БРГМ мозку в контрольній і основній групах

Table 3. FA of cerebral ROI of WM in the control and main groups

\begin{tabular}{|c|c|c|c|c|c|}
\hline \multirow[t]{2}{*}{$\begin{array}{l}\text { Показник } \\
\text { Categorie }\end{array}$} & \multicolumn{2}{|c|}{$\begin{array}{c}\text { Контрольна група } \\
\text { Control group } \\
(n=19)\end{array}$} & \multicolumn{2}{|c|}{$\begin{array}{l}\text { Основна група } \\
\text { Main group } \\
(n=34)\end{array}$} & \multirow[t]{2}{*}{ p } \\
\hline & Me & $Q_{1}-Q_{I I I}$ & Me & $\mathbf{Q}_{1}-\mathbf{Q}_{\mathrm{III}}$ & \\
\hline \multicolumn{6}{|c|}{ FA права півкуля / FA right hemisphere } \\
\hline ПФД/PF & 0,293 & $0,287-0,294$ & 0,230 & $0,215-0,246$ & $<0,001$ \\
\hline ОФД/OF & 0,268 & $0,262-0,268$ & 0,216 & $0,197-0,230$ & $<0,001$ \\
\hline ТД/Р & 0,286 & $0,280-0,290$ & 0,245 & $0,238-0,264$ & $<0,001$ \\
\hline ПД/Ос & 0,313 & $0,305-0,323$ & 0,261 & $0,257-0,298$ & $<0,001$ \\
\hline СД/Т & 0,316 & $0,309-0,320$ & 0,282 & $0,266-0,315$ & 0,004 \\
\hline ППВД/PVant & 0,423 & $0,418-0,426$ & 0,341 & $0,316-0,348$ & $<0,001$ \\
\hline COЦ/SOC & 0,441 & $0,428-0,445$ & 0,328 & $0,292-0,335$ & $<0,001$ \\
\hline \multicolumn{6}{|c|}{ FA ліва півкуля / FA left hemisphere } \\
\hline ПФД/PF & 0,297 & $0,294-0,301$ & 0,241 & $0,219-0,251$ & $<0,001$ \\
\hline ОФД/ОF & 0,254 & $0,249-0,257$ & 0,212 & $0,202-0,220$ & $<0,001$ \\
\hline ТД/Р & 0,284 & $0,280-0,289$ & 0,257 & $0,230-0,275$ & $<0,001$ \\
\hline ПД/Ос & 0,328 & $0,327-0,333$ & 0,252 & $0,232-0,262$ & $<0,001$ \\
\hline СД/Т & 0,323 & $0,317-0,325$ & 0,279 & $0,274-0,309$ & $<0,001$ \\
\hline ППВД/PVant & 0,411 & $0,407-0,414$ & 0,326 & $0,296-0,360$ & $<0,001$ \\
\hline coL/SOC & 0,456 & $0,453-0,459$ & 0,303 & $0,280-0,324$ & $<0,001$ \\
\hline
\end{tabular}

\section{Примітки:}

Закон розподілу показників відрізнявся від нормального ( $p<0,05$ за критерієм Шапіро-Вілка), для представлення даних розраховано медіанне значення (Ме) та міжквартильний інтервал $\left(Q_{1}-Q_{\text {III }}\right)$. Для проведення порівняння використано критерій Манна-Уїтні.

Notes:

The law of distribution of indicators differed from normal ( $p<0.05$ according to the Shapiro-Wilk criterion), the median value (Me) and the interquartile range $\left(Q_{1}-Q_{I I I}\right)$ were calculated for data presentation. The Mann-Whitney test was used for comparison. 
Таблиця 4. MD провідних шляхів головного мозку в контрольній і основній групах Table 4. MD of cerebral fiber tracts in the control and main groups

\begin{tabular}{|c|c|c|c|c|c|}
\hline \multirow[t]{2}{*}{$\begin{array}{l}\text { Показник } \\
\text { Categorie }\end{array}$} & \multicolumn{2}{|c|}{$\begin{array}{c}\text { Контрольна група } \\
\text { Control group } \\
(n=19)\end{array}$} & \multicolumn{2}{|c|}{$\begin{array}{l}\text { Основна група } \\
\text { Main group } \\
(n=34)\end{array}$} & \multirow[t]{2}{*}{ p } \\
\hline & Me & $Q_{1}-Q_{111}$ & Me & $Q_{1}-Q_{111}$ & \\
\hline \multicolumn{6}{|c|}{ MD (× 10-3 $\left.\mathrm{MM}^{2} / \mathrm{c}\right)$ права півкуля / MD $\left(\times 10^{-3} \mathrm{~mm}^{2} / \mathrm{s}\right)$ right hemisphere } \\
\hline ВПП /SLF & 0,699 & $0,687-0,709$ & 0,788 & $0,761-0,800$ & $<0,001$ \\
\hline$\Pi / C$ & 0,668 & $0,653-0.678$ & 0,799 & $0,786-0,817$ & $<0,001$ \\
\hline$\Gamma \Pi / F U$ & 0,626 & $0,620-0,631$ & 0,828 & $0,796-0,846$ & $<0,001$ \\
\hline $\mathrm{H} \Pi \Pi / I L F$ & 0,757 & $0,746-0,778$ & 0,833 & $0,820-0,891$ & $<0,001$ \\
\hline \multicolumn{6}{|c|}{$\mathrm{MD}\left(\times 10^{-3} \mathrm{Mm}^{2} / \mathrm{c}\right)$ ліва півкуля / MD $\left(\times 10^{-3} \mathrm{~mm}^{2} / \mathrm{s}\right)$ left hemisphere } \\
\hline ВПП /SLF & 0,697 & $0,685-0,702$ & 0,782 & $0,777-0,808$ & $<0,001$ \\
\hline$\Pi / C$ & 0,682 & $0,677-0,690$ & 0,793 & $0,776-0,815$ & $<0,001$ \\
\hline ГП/FU & 0,613 & $0,605-0,627$ & 0,804 & $0,777-0,836$ & $<0,001$ \\
\hline HПП/ILF & 0,714 & $0,709-0,717$ & 0,849 & $0,843-0,891$ & $<0,001$ \\
\hline \multicolumn{6}{|c|}{$\mathrm{MD}\left(\times 10^{-3} \mathrm{MM}^{2} / \mathrm{c}\right) \mathrm{MT} / \mathrm{MD}\left(\times 10^{-3} \mathrm{~mm}^{2} / \mathrm{s}\right) \mathrm{CC}$} \\
\hline KMT/GCC & 0,690 & $0,686-0,699$ & 0,798 & $0,758-0,817$ & $<0,001$ \\
\hline BMT/SCC & 0,677 & $0,661-0,702$ & 0,791 & $0,767-0,826$ & $<0,001$ \\
\hline
\end{tabular}

\section{Примітки:}

Закон розподілу показників відрізнявся від нормального ( $p<0,05$ за критерієм Шапіро-Вілка), для представлення даних розраховано медіанне значення (Мe) та міжквартильний інтервал $\left(Q_{1}-Q_{\| I}\right)$. Для проведення порівняння використано критерій Манна-Уїтні.

Notes:

The law of distribution of indicators differed from normal ( $p<0.05$ according to the Shapiro-Wilk criterion), the median value (Me) and the interquartile range $\left(Q_{1}-Q_{I I I}\right)$ were calculated for data presentation. The Mann-Whitney test was used for comparison.

Таблиця 5. MD ROI БРГМ мозку в контрольній і основній групах

Table 5. MD of cerebral ROI of WM in the control and main groups

\begin{tabular}{|c|c|c|c|c|c|}
\hline \multirow[t]{2}{*}{$\begin{array}{l}\text { Показник } \\
\text { Categorie }\end{array}$} & \multicolumn{2}{|c|}{$\begin{array}{c}\text { Контрольна група } \\
\text { Control group } \\
(n=19)\end{array}$} & \multicolumn{2}{|c|}{$\begin{array}{l}\text { Основна група } \\
\text { Main group } \\
(n=34)\end{array}$} & \multirow[t]{2}{*}{ p } \\
\hline & Me & $Q_{1}-Q_{I I I}$ & Me & $Q_{1}-Q_{I I I}$ & \\
\hline \multicolumn{6}{|c|}{$\mathrm{MD}\left(\times 10^{-3} \mathrm{MM}^{2} / \mathrm{c}\right)$ права півкуля / MD $\left(\times 10^{-3} \mathrm{~mm}^{2} / \mathrm{s}\right)$ right hemisphere } \\
\hline ПФД/РF & 0,834 & $0,827-0,843$ & 1,054 & $1,009-1,111$ & $<0,001$ \\
\hline ОФД/OF & 0,824 & $0,817-0,832$ & 1,040 & $1,017-1,100$ & $<0,001$ \\
\hline ТД/Р & 0,739 & $0,734-0,747$ & 1,026 & $0,980-1,061$ & $<0,001$ \\
\hline ПД/Ос & 0,798 & $0,788-0,803$ & 0,920 & $0,861-0,962$ & $<0,001$ \\
\hline СД/Т & 0,869 & $0,863-0,878$ & 0,975 & $0,943-1,012$ & $<0,001$ \\
\hline ППВД/PVant & 0,863 & $0,859-0,869$ & 0,969 & $0,943-0,986$ & $<0,001$ \\
\hline COЦ/SOC & 0,814 & $0,808-0,819$ & 0,908 & $0,858-0,943$ & $<0,001$ \\
\hline \multicolumn{6}{|c|}{ MD (× $\left.10^{-3} \mathrm{MM}^{2} / \mathrm{c}\right)$ ліва півкуля / MD $\left(\times 10^{-3} \mathrm{~mm}^{2} / \mathrm{s}\right)$ left hemisphere } \\
\hline ПФД/РF & 0,829 & $0,822-0,833$ & 1,003 & $0,997-1,066$ & $<0,001$ \\
\hline ОФД/ОF & 0,840 & $0,835-0,845$ & 1,014 & $0,987-1,111$ & $<0,001$ \\
\hline ТД/Р & 0,838 & $0,834-0,853$ & 1,002 & $0,968-1,051$ & $<0,001$ \\
\hline ПД/Ос & 0,789 & $0,781-0,794$ & 0,935 & $0,882-0,976$ & $<0,001$ \\
\hline СД/Т & 0,900 & $0,894-0,908$ & 1,001 & $0,953-1,028$ & $<0,001$ \\
\hline ППВД/PVant & 0,888 & $0,822-0,893$ & 0,963 & $0,938-0,982$ & $<0,001$ \\
\hline COЦ/SOC & 0,808 & $0,798-0,815$ & 0,889 & $0,857-0,962$ & $<0,001$ \\
\hline
\end{tabular}

\section{Примітки:}

Закон розподілу показників відрізнявся від нормального ( $p<0,05$ за критерієм Шапіро-Вілка), для представлення даних розраховано медіанне значення (Ме) та міжквартильний інтервал $\left(Q_{1}-Q_{\text {III }}\right)$. Для проведення порівняння використано критерій Манна-Уїтні.

Notes:

The law of distribution of indicators differed from normal ( $p<0.05$ according to the Shapiro-Wilk criterion), the median value (Me) and the interquartile range $\left(Q_{1}-Q_{I I I}\right)$ were calculated for data presentation. The Mann-Whitney test was used for comparison. 
За результатами нейропсихологічного обстеження із застосуванням шкали МоСА відхилення від контрольних показників (Me $\left.=23 ; \mathrm{Q}_{1}-\mathrm{Q}_{\mathrm{III}}=21-23\right)$, що відповідають помірним когнітивним порушенням (ПКП), виявлено у 29 з 34 (85,3\%) хворих (табл. 6). Відповідно до даних статистичного аналізу, достовірно зменшеними були суми балів опитувальника МоCA у доменах EIS, VIS, LIS i AIS $(p<0,001)$.
According to the results of neuropsychological examination using the MoSA scale, deviations from the control parameters $\left(\mathrm{Me}=23 ; \mathrm{Q}_{1}-\mathrm{Q}_{\mathrm{III}}=21-23\right)$, corresponding to moderate cognitive impairment $(\mathrm{MCl})$, were found in 29 out of $34(85.3 \%)$ patients (Table 6$)$. According to the statistical analysis, the total of MoSA questionnaire scores in the EIS, VIS, LIS and AIS domains were significantly reduced $(p<0.001)$.

Таблиця 6. Результати тестування за шкалою МоСА контрольної та основної груп досліджуваних середнього віку Table 6. The results of testing on the MoCA scale of the control and main groups of middle-aged subjects

\begin{tabular}{|c|c|c|c|c|c|}
\hline \multirow{2}{*}{$\begin{array}{l}\text { Показник } \\
\text { Categorie }\end{array}$} & \multicolumn{2}{|c|}{$\begin{array}{c}\text { Контрольна група / Control group } \\
(n=19)\end{array}$} & \multicolumn{2}{|c|}{$\begin{array}{l}\text { Основна група / Main group } \\
(n=34)\end{array}$} & \multirow{2}{*}{ p } \\
\hline & Me & $Q_{1}-Q_{\| I I}$ & Me & $\mathbf{Q}_{1}-\mathbf{Q}_{\mathrm{III}}$ & \\
\hline MOCA $\Sigma$ & 27 & $27-28$ & 23 & $21-24$ & $<0,001$ \\
\hline EIS & 12 & $12-12$ & 10 & $8-10$ & $<0,001$ \\
\hline VIS & 7 & $7-7$ & 6 & $5-7$ & $<0,001$ \\
\hline LIS & 5 & $5-6$ & 4 & $4-5$ & $<0,001$ \\
\hline AIS & 18 & $17-18$ & 16 & $15-16$ & $<0,001$ \\
\hline OIS & 6 & $6-6$ & 6 & $6-6$ & $>0,999$ \\
\hline MIS & 12 & $10,5-13$ & 13 & $10-13$ & 0,664 \\
\hline
\end{tabular}

\section{Примітки:}

Закон розподілу показників відрізнявся від нормального ( $p<0,05$ за критерієм Шапіро-Уілка), для представлення даних розраховано медіанне значення (Ме) та міжквартильний інтервал $\left(Q_{1}-Q_{1 I}\right)$. Для проведення порівняння використано критерій Манна-Уітні. Notes:

The law of distribution of indicators differed from normal ( $p<0.05$ according to the Shapiro-Wilk criterion), the median value (Me) and the interquartile range $\left(Q_{1}-Q_{1 I I}\right)$ were calculated for data presentation. The Mann-Whitney test was used for comparison.

Виявилось, що для ранніх ПКП у пацієнтів із ЦХМС притаманний неамнестичний (MIS: $\mathrm{Me}=133$; $\left.Q_{1}-Q_{I I I}=10-13, p=0,664\right)$ полідоменний характер. Питома вага спостережень погіршення виконавчої функції (EIS) була найбільшою (31 (91,2\%)) і складала $79,4 \%, 76,5 \%$ і 67,6\% у доменах AIS, VIS i LIS, відповідно. Когнітивні розлади одночасно в 5 доменах, у тому числі й пам'яті, діагностовано тільки у трьох хворих.

Визначення кореляційних зв'язків між виразністю візуальних МРТ маркерів ТЦХМС та ступенем ментальних розладів не виявило ознак впливу ранніх змін ГБРГМ на стан пам'яті (MIS) та орієнтації у просторі й часі (OIS). Цілком закономірним видається існування помірної негативної кореляції між виразністю ГІГБРГМ, доменами EIS $(-0,402)$, VIS $(-0,373)$, LIS $(-0,337)$, AIS $(-0,375)$ та сумарними оцінками MoCA $(-0,429)$.

ГІПВГБРГМ на початку свого утворення (1-2 бали ТЦХМСр) не сприяла погіршенню розумової діяльності. Збільшення кількості та ступеня розширень периваскулярних просторів було помірно та негативно пов'язано 3 концентрацією уваги та виконавчими функціями (AIS: $r s=-0,419$; EIS: $r s=-0,319$ ).

Показники рангової кореляції Спірмена між результатами тестування за шкалою МоСА та показниками DTI MPT наведені в таблиці 7. Встановлено, що ранні помірні когнітивні порушення ( $(\mathrm{MoCA})$ при церебральній хворобі малих судин у середньому віці перебувають у позитивному (помірному/помітному) кореляційному зв'язку з показниками FA волокон: верхніх поздовжніх пучків, гачкуватих пучків і валику мозолистого тіла тa ROI: семіовальних центрів, префронтальних і орбітофронтальних ділянок (rs $=0,412-0,594)$. Негативно позначається на стані ментальних фрункцій білатеральне зростання середнього коефіцієнта дифузії (MD) у гачкуватих пучках, коліні й валику мозолистого тіла,
We found that non-amnestic (MIS: $\mathrm{Me}=133$; $Q_{1}-Q_{I I I}=10-13, p=0.664$ ) polydomain character is typical of early $\mathrm{MCl}$ in patients with CSVD. The share of performance degradation (EIS) observations was the highest (31 $(91.2 \%)$ ), and was $79.4 \%, 76.5 \%$ and $67.6 \%$ in the AIS, VIS and LIS domains, respectively. Cognitive disorders in 5 domains simultaneously, including memory, were diagnosed in only three patients.

The correlation between the severity of visual MRI markers of BcSVD and the degree of mental disorders did not reveal signs of the early changes in $\mathrm{WMH}$ on memory (MIS) and orientation in space and time (OIS). The existence of a moderate negative correlation between the expression of DWMH, EIS (-0.402), VIS (-0.373), LIS $(-0.337)$, AIS $(-0.375)$ and total MoSA estimates $(-0.429)$ seems quite natural.

PVWMH at the beginning of its formation (1-2 points BcSVDearly) did not contribute to the deterioration of mental activity. The increase in the number and degree of expansion of perivascular spaces was moderately and negatively associated with concentration and executive functions (AIS: rs = -0,419; EIS: $r s=-0,319$ ).

Spearman's rank correlation between MoCA test results and DTI MRI results is shown in Table 7 . We found that early moderate cognitive impairment ( $\Sigma \mathrm{MoCA})$ in middle cerebral vascular disease in the middle age is in a positive (moderate/noticeable) correlation with indica-tors of FA fibers: upper longitudinal bundles, hooked bundles and splenium of the corpus callosum and ROI: semioval centers, prefrontal and orbitofrontal areas ( $r s=0.412-0.594$ ). The state of mental functions is negatively affected by the bilateral increase of the average diffusion coefficient (MD) in hooked bundles, genu and splenium of the corpus callosum, orbitofrontal, parietal, occipital and anterior periventricular areas $(r s=-0.448-(-0.574))$. 
орбітофронтальних, тім'яних, потиличних і передніх перивентрикулярних ділянках ( rs $=-0,448-(-0,574))$.

Таблиця 7. Рангова кореляція Спірмена (rs)

між довізуальними маркерами ЦХМС і показниками шкали МоСА у хворих середнього віку

Table 7. Spearman rank correlation ( $\mathrm{rs}$ ) between previsual markers of CSVD and MoCA scale in middle-aged patients

\begin{tabular}{|c|c|}
\hline$\sum$ MoCA & 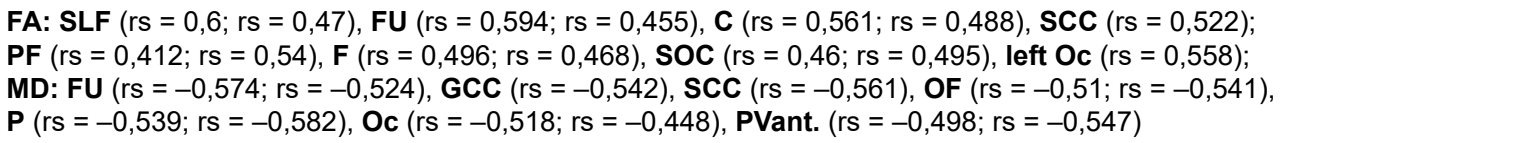 \\
\hline EIS & $\begin{array}{l}\text { FA: FU ( } r s=0,487 ; r s=0,462) ; \\
\text { MD: FU ( }(r s=-0,497 ; r s=-0,45) \text {, OF ( } r s=-0,465 ; r s=-0,465), P(r s=-0,531 ; r s=-0,53) \text {, } \\
\text { PVant. }(r s=-0,498 ; r s=-0,457)\end{array}$ \\
\hline VIS & 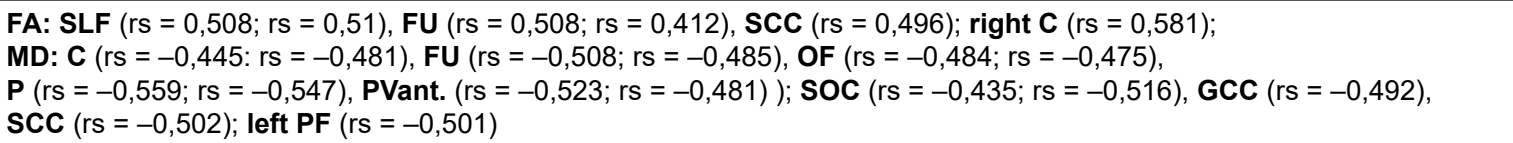 \\
\hline LIS & 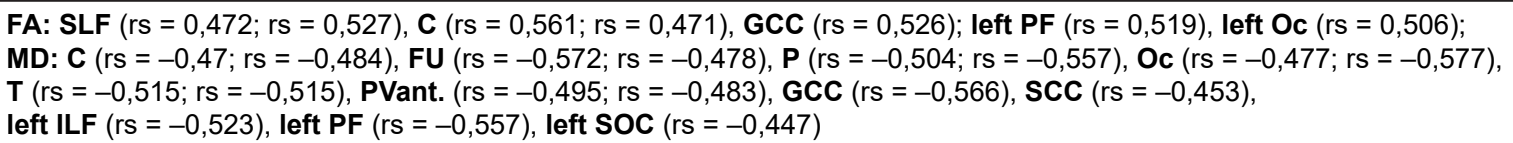 \\
\hline AIS & 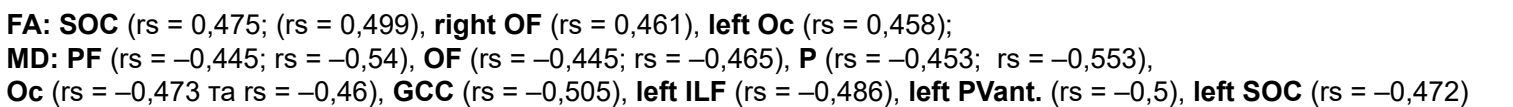 \\
\hline
\end{tabular}

Примітка / Notes: Spearman Rank $(\mathrm{p}<0.05)$

Аналіз результатів клініко-нейровізуалізаційних обстежень пацієнтів середнього віку на початку захворювання на спорадичну церебральну мікроангіопатію дозволив дійти таких висновків.

\section{вИСновки}

1. За результатами мультипараметричної МРТ визначено ранні візуальні ознаки асоційованої 3 артеріальною гіпертензією церебральної хвороби малих судин: розширені периваскулярні простори та гіперінтенсивність перивентрикулярної глибокої білої речовини головного мозку (сумарна оцінка за шкалою ТЦХМСр до 4 балів). Ранніми довізуальними проявами захворювання визнано зменшення на 9-33,6\% коефіцієнта фрракційної анізотропії та зростання на 20,8-28,0\% від контрольних показників середнього коефріцієнта дифузії. Мультицентричний мозаїчний характер МРТ змін глибокої білої речовини головного мозку свідчить на користь дифузного характеру її структурної перебудови.

2. Встановлено, що виразність ранніх клінічних проявів спорадичної неамілоїдної мікроангіопатії (неамнестичні полідоменні помірні порушення уваги, мовлення, візуально-просторової та виконавчої когнітивних функцій) перебувають у помірному/помітному кореляційному зв'язку із показниками ТХMCp, коефріцієнта MD (позитивний) i FA (негативний).
Analysis of the results of clinical and neuroimaging examinations of middle-aged patients at the beginning of the disease of sporadic cerebral microangiopathy allowed us to draw the following conclusions.

\section{CONCLUSIONS}

1. The results of multiparametric MRI revealed early visual signs of cerebrovascular disease associated with hypertension: dilated perivascular spaces and hyperintensity of the periventricular deep white matter of the brain (total score according to BcSVDearly scale up to 4 points). Early pre-visual manifestations of the disease were defined as a decrease by $9-33.6 \%$ in the fractional anisotropy coefficient and an increase by $20.8 \%$ to $28.0 \%$ of the control values of the average diffusion coefficient. The multicentric mosaic nature of MRI changes in the deep white matter of the brain indicates in favor of the diffuse nature of its structural adjustment.

2. We found that the severity of early clinical manifestations of sporadic non-amyloid microangiopathy (non-amnestic polydomain moderate disorders of attention, speech, visual-spatial and executive cognitive functions) are in a moderate/noticeable correlation with BcSVDearly values, MD coefficient (positive) and FA (negative).

\section{СПИСОК ВИКОРИСТАНОÏ ЛІТЕРАТУРИ}

1. Кулеш А.А., Дробаха В.Е., Шестаков В.В. Церебральная болезнь мелких сосудов: классификация, клинические проявления, диагностика и особенности лечения. Неврология, нейропсихиатрия, психосоматика. 2019. № 11(3). C. 4-17.

2. Wardlaw J. M., Debette S., Jokinen H., De Leeuw F. E. etal. ESO Guideline on covert cerebral small vessel disease. Stroke Journal. 2021. Vol. 6(2) P. CXI-CLXII. DOI: https://doi.org/10.1177/23969873211012132

3. Garcia-Ptacek S., Eriksdotter M., Jelic V. et al. Subjective cognitive impairment: Towards early identification of Alzheimer disease.

\section{REFERENCES}

1. Kulesh AA, Drobakha VE, Shestakov VV. Cerebral small vessel disease classification, clinical manifestations, diagnosis, and features of treatment. Neurology, Neuropsychiatry, Psychosomatics. 2019;11(3):4-17. (In Russian). DOI: https://doi.org/10.14412/2074-2711-2019-3S-4-17

2. Wardlaw JM, Debette S, Jokinen H, De Leeuw FE et al. ESO Guideline on covert cerebral small vessel disease. Stroke Journal. 2021;6(2):CXI-LXII. (In English). DOI: https://doi.org/10.1177/23969873211012132

3. Garcia-Ptacek S, Eriksdotter M, Jelic V et al. Subjective cognitive impairment: Towards early identification of Alzheimer disease. 
Neurology. 2016. Vol. 31(8). P. 562-571. DOI: https://doi.org/10.1016/ j.nrl.2013.02.007

4. Szcześniak D., Rymaszewska J., Zimny A. et al. Cerebral small vessel disease and other influential factors of cognitive impairment in the middle-aged: a long-term observational cohort PURE-MIND study in Poland. GeroScience. 2021. Vol. 43. P. 279-289. DOI: https://doi.org/10.1007/s11357-020-00271-4

5. Lau K.K., Li L., Simoni M. et al. Long-term premorbid blood pressure and cerebral small vessel disease burden on imaging in transient ischemic attack and ischemic stroke. Stroke. 2018. Vol. 49(9) P. 2053-2060. DOI: https://doi.org/10.1161/STROKEAHA.118.021578

6. Shi Y., Wardlaw J.M. Update on cerebral small vessel disease: a dynamic whole-brain disease. Stroke and Vascular Neurology. 2016. Vol. 1. e000035 p. DOI: https://doi.org/10.1136/svn-2016-000035

7. Wardlaw J.M., Smith E E., Biessels G.J. et al. Neuroimaging standards for research into small vessel disease and its contribution to ageing and neurodegeneration. Lancet Neurol. 2013. Vol. 12. P. 822-838. DOI: https://doi.org/10.1016/S1474-4422(13)70124-8

8. Міщенко Т.С., Нікішкова І.М., Міщенко В.М., Кутіков Д.О. Церебральна атроффія при хворобі малих судин головного мозку. Міжнародний неврологічний журнал. 2016. Vol. 8(86). C.13-19.

9. Croall I.D., Lohner V., Moynihan B. et al. Using DTI to assess white center studies. Clinical Sciences. 2017. Vol. 131(12). P. 1361-1373. DOI: https://doi.org/10.1042/CS20170146 graphy in cerebral small vessel disease: correlation with cognitive function. Neuroradiologic Journal. 2018. Vol. 31(1). P. 83-89. DOI: https://doi.org/10.1177/1971400916682753

11. Biesbroek J.M., Leemans A., Den Bakker H. et al. Microstructure of strategic white matter tracts and cognition in memory clinic patients with vascular brain injury. Demential Geriatric Cognitive Disorders. 2017. Vol. 44. P. 268-282. DOI: https://doi.org/10.1159/000485376

12. Brown R., Benveniste H., Black S.E. et al. Understanding the role of the perivascular space in cerebral small vessel disease. Cardiovascular Research. 2018. Vol. 114(11). P. 1462-1473. DOI: https://doi.org/10.1093/cvr/cvy113

13. Carson N., Leach L., Murphy J. A re-examination of Montreal Cognitive Assessment (MoCA) cutoff scores. International Journal of Geriatric Psychiatry. 2018. P. 379-388. DOI: https://doi.org/10.1002/gps.4756

14. Дикан І.М., Головченко Ю.І., Семьонова О.В. Особливості ранньої МРТ діагностики церебральної хвороби малих судин у хворих на артеріальну гіпертензію та цукровий діабет 2 типу. Проблеми ендокринної патології. 2020. № 4. С. 39-47. DOI: https://doi.org/10.21856/j-PEP.2020.4.05 matter microstructure in cerebral small vessel disease (SVD) in multi-

10. D'Souza M. M., Gorthi S. P., Vadwala K. et al. Diffusion tensor tracto-

Neurology. 2016;31(8):562-71. (In English). DOI: https://doi.org/ 10.1016/j.nrl.2013.02.007

4. Szcześniak D, Rymaszewska J, Zimny A et al. Cerebral small vessel disease and other influential factors of cognitive impairment in the middle-aged: a long-term observational cohort PURE-MIND study in Poland. GeroScience. 2021;43:279-89. (In English). DOI: https://doi.org/10.1007/s11357-020-00271-4

5. Lau KK, Li L, Simoni M et al. Long-term premorbid blood pressure and cerebral small vessel disease burden on imaging in transient ischemic attack and ischemic stroke. Stroke. 2018;49(9):2053-60. (In English). DOI: https://doi.org/10.1161/STROKEAHA. 118.021578

6. Shi Y, Wardlaw JM. Update on cerebral small vessel disease: a dynamic whole-brain disease. Stroke and Vascular Neurology. 2016;1:e000035. (In English). DOI: https://doi.org/10.1136/svn-2016-000035

7. Wardlaw JM, Smith EE, Biessels GJ et al. Neuroimaging standards for research into small vessel disease and its contribution to ageing and neurodegeneration. Lancet Neurol. 2013;12:822-38. (In English). DOI: https://doi.org/10.1016/S1474-4422(13)70124-8

8. Mishhenko TS, Nikishkova IM, Mishhenko VM, Kutikov DO. Cerebral atrophy in cerebral small vessel disease. International Journal of Neurology. 2016;8(86):13-9. (In Ukrainian).

9. Croall ID, Lohner V, Moynihan B et al. Using DTI to assess white matter microstructure in cerebral small vessel disease (SVD) in multicenter studies. Clinical Sciences. 2017;131(12):1361-73. (In English). DOI: https://doi.org/10.1042/CS20170146

10. D'Souza MM, Gorthi SP, Vadwala K et al. Diffusion tensor tractography in cerebral small vessel disease: correlation with cognitive function. Neuroradiologic Journal. 2018;31(1):83-9. (In English). DOI: https://doi.org/10.1177/1971400916682753

11. Biesbroek JM, Leemans A, Den Bakker $\mathrm{H}$ et al. Microstructure of strategic white matter tracts and cognition in memory clinic patients with vascular brain injury. Demential Geriatric Cognitive Disorders. 2017;44:268-82. (In English). DOI: https://doi.org/10.1159/000485376

12. Brown R, Benveniste $\mathrm{H}$, Black SE et al. Understanding the role of the perivascular space in cerebral small vessel disease. Cardiovascular Research. 2018;114(11):1462-73. (In English). DOI: https://doi.org/10.1093/cvr/cvy113

13. Carson N, Leach L, Murphy J. A re-examination of Montreal Cognitive Assessment (MoCA) cutoff scores. International Journal of Geriatric Psychiatry. 2018;379-88. (In English). DOI: https://doi.org/ 10.1002/gps. 4756

14. Dykan IM, Golovchenko YI, Semonova OV et al. Features of early MRI diagnosis of cerebral small vessel disease in patients with arterial hypertension and diabetes mellitus type 2. Problems of Endocrine Pathology. 2020;74(4):39-47. (In Ukrainian). DOI: https://doi.org/10.21856/j-PEP.2020.4.05

Перспективи подальших досліджень

Prospects for further research

Отримані авторами наукові результати започатковують серію досліджень, метою яких будуть:

- диференційна діагностика дифузних захворювань білої речовини головного мозку;

- розробка науково-обґрунтованих алгоритмів моніторингу спостереження та лікування пацієнтів з ранньою церебральною хворобою малих судин з метою профілактики судинної деменції.

Конфрлікт інтересів

Conflict of interest

Автори рукопису свідомо засвідчують відсутність фрактичного або потенційного конфлікту інтересів щодо результатів цієї роботи з фармацевтичними компаніями, виробниками біомедичних пристроїв, іншими організаціями, чиї продукти, послуги, фінансова підтримка можуть бути пов'язані з предметом наданих матеріалів або які спонсорували проведені дослідження.
The scientific results obtained by the authors initiate a series of studies aimed at:

- differential diagnosis of diffuse diseases of the white matter of the brain;

- development of scientifically based algorithms for monitoring the observation and treatment of patients with early cerebral disease of small vessels in order to prevent vascular dementia; etc.
The authors of the manuscript knowingly acknowledge the absence of actual or potential conflict of interest regarding the results of this paper with pharmaceutical companies, manufacturers of biomedical devices, other organizations whose products, services, financial support may be related to the subject of materials or who sponsored research.
The study is being carried out on the researcher's initiative at his/her expense.

\section{ВІДОМОСТІ ПРО АВТОРІВ}

Семьонова Олександра Володимирівна - аспірант кафедри неврології №1 Національного університету охорони здоров'я України ім. П.Л. Шупика; лікар-невролог Державної установи «Інститут ядерної медицини та променевої

\section{INFORMATION ABOUT AUTHORS}

Semonova Olexandra Volodymyrivna - Postgraduate student of Neurology Department No 1 of Shupyk National Healthcare University of Ukraine, Neurologist of State Institution «Institute Nuclear of Medicine and Diagnostic Radiology of National Academy 
діагностики Національної академії медичних наук України»; вул. Платона Майбороди, буд. 32, м. Київ, Україна, 04050; e-mail: al.semenova@i.ua моб.: +38 (063) 861-36-96

Внесок автора: дизайн наукового дослідження та координація обстежень пацієнтів; клінічне спостереження хворих, зіставлення даних нейропсихологічних та нейровізуалізаційних досліджень; аналіз отриманих результатів, висновки.

Мироняк Людмила Анатоліївна - кандидат медичних наук, завідуюча відділом МРТ Державної установи «Інститут ядерної медицини та променевої діагностики Національної академії медичних наук України»; вул. Платона Майбороди, буд. 32, м. Київ, Україна, 04050;

e-mail: L.myronyak2017@gmail.com

моб.: +38 (067) 407-37-66

Внесок автора: розробка програм та виконання мультипараметричної МРT, зіставлення даних з результатами допплерографрічних досліджень церебрального кровотоку; аналіз отриманих результатів, висновки.

Глазовська Ірина Іванівна - кандидат медичних наук, завідуюча консультативно-поліклінічним відділом Державної установи «Інститут ядерної медицини та променевої діагностики Національної академії медичних наук України»; вул. Платона Майбороди, буд. 32, м. Київ, Україна, 04050;

e-mail: iglazovska@gmail.com

моб.: +38 (050) 175-78-43

Внесок автора: клінічне та нейропсихологічне обстеження хворих та умовно здорових осіб контрольних груп, допплерографрічні дослідження иеребрального кровотоку; аналіз отриманих результатів, висновки.

Іванова Марина Федорівна - кандидат медичних наук, заступник головного лікаря Державної установи «Інститут ядерної медицини та променевої діагностики Національної академії медичних наук України»; вул. Платона Майбороди, буд. 32, м. Київ, Україна, 04050;

e-mail:mf_ivanova@i.ua

моб.: +38 (050) 949-95-00

Внесок автора: клінічне спостереження та нейропсихологічне обстеження хворих та умовно здорових осіб контрольних груп, зіставлення даних нейропсихологічних та нейровізуалізаційних досліджень, аналіз отриманих результатів, висновки.

Красюк Олександр Володимирович - доктор медичних наук, професор кафедри терапії Української військовомедичної академії Міністерства охорони здоров'я України; вул. Московська, буд. 45/1, корпус 33, Київ, Україна, 01015;

e-mail: alexkrasyuk@ukr.net

моб.: +38 (067) 260-27-60

Внесок автора: формування критеріїв включення та виключення пацієнтів до наукового дослідження, координація клінічних та нейропсихологічних досліджень, аналіз отриманих результатів, висновки. of Medical Science of Ukraine», 32, Platona Mayiborody Str., Kyiv, Ukraine, 04050;

e-mail: al.semenova@i.ua

tel.: +38 (063) 861-36-96

Author's contribution: research design and coordination of patient examinations; clinical observation of patients, comparison of data from neuropsychological and neuroimaging studies; analysis of the obtained results, conclusions.

Myronyak Ludmyla Anatoliivna - Candidate of Medical Sciences, Chief of MRI Department of State institution «Institute Nuclear Medicine and Diagnostic Radiology of National Academy of Medical Science of Ukraine»; 32, Platona Mayiborody Str., Kyiv, Ukraine, 04050;

e-mail: L.myronyak2017@gmail.com

tel.: +38 (067) 407-37-66

Author's contribution: development of programs and implementation of multiparametric MRI, comparison of data with the results of Doppler studies of cerebral blood flow; analysis of the obtained results, conclusions.

Glazovska Iryna Ivanivna - Candidate of Medical Sciences, Chief of the Consulting and Outpatient department of State institution «Institute Nuclear Medicine and Diagnostic Radiology of National Academy of Medical Science of Ukraine»; 32, Platona Mayiborody Str., Kyiv, Ukraine, 04050;

e-mail: iglazovska@gmail.com

tel.: +38 (050) 175-78-43

Author's contribution: clinical and neuropsychological examination of patients and conditionally healthy individuals of control groups, Doppler studies of cerebral blood flow; analysis of the obtained results, conclusions.

Ivanova Maryna Fedorivna - Candidate of Medical Sciences, Deputy Chief Physician of State institution «Institute Nuclear Medicine and Diagnostic Radiology of National Academy of Medical Science of Ukraine»; 32, Platona Mayiborody Str., Kyiv, Ukraine, 04050;

e-mail:mf_ivanova@i.ua

tel.: +38 (050) 949-95-00

Author's contribution: clinical observation and neuropsychological examination of patients and relatively healthy individuals of control groups, comparison of data from neuropsychological and neuroimaging studies, analysis of the results, conclusions.

Krasyuk Olexandr Anatoliovich - Doctor of Medical Sciences, Professor of Therapy Department of Military Medical Academy of Ukraine of the Ministry of Health of Ukraine; 45/1, b. 33, Moskovska Str., Kyiv, Ukraine, 01015;

e-mail: alexkrasyuk@ukr.net

tel.: +38 (067) 260-27-60

Author's contribution: formation of criteria for inclusion and exclusion of patients in scientific research, coordination of clinical and neuropsychological research, analysis of the results, conclusions.

\begin{tabular}{cccc}
\hline Рукопис надійшов & Отримано після рецензування & Прийнято до друку & Опубліковано \\
Manuscript was received & Received after review & Accepted for printing & Published \\
07.09 .2021 & 19.09 .2021 & 28.09 .2021 & 29.09 .2021 \\
\hline
\end{tabular}

